\title{
GSK3A Gene
}

National Cancer Institute

\section{Source}

National Cancer Institute. GSK3A Gene. NCI Thesaurus. Code C42618.

This gene is involved in carbohydrate metabolism, signal transduction and the regulation of apoptosis. 